\title{
Inhaltsangabe mit Themenübersicht
}

\begin{tabular}{|c|c|c|}
\hline \multirow[t]{2}{*}{1} & $\begin{array}{l}\text { Globalisierung - Herausforderung oder Verhängnis? } \\
\text { Die Argumente der Globalisierungsbefürworter und -gegner }\end{array}$ & 2 \\
\hline & $\begin{array}{l}\text { Free Trade - A Will-O'-The-Wisp? } \\
\text { Pros and cons of free trade }\end{array}$ & 10 \\
\hline \multirow[t]{2}{*}{2} & $\begin{array}{l}\text { Produkte im Wandel der Zeit - von Waren und } \\
\text { Dienstleistungen zu Solutions } \\
\text { Die Entwicklung von Waren und Dienstleistungen im historischen Überblick }\end{array}$ & 20 \\
\hline & $\begin{array}{l}\text { Whose Idea Was It Anyway? } \\
\text { Intellectual property rights and branding }\end{array}$ & 24 \\
\hline \multirow[t]{2}{*}{3} & $\begin{array}{l}\text { Markterschließung und Kundenakquisition im Ausland } \\
\text { Klassischer Maßnahmenkatalog zur Erschließung neuer Absatzmärkte }\end{array}$ & 36 \\
\hline & $\begin{array}{l}\text { The World's Your Oyster } \\
\text { Intercultural dimensions of product promotion }\end{array}$ & 42 \\
\hline \multirow[t]{2}{*}{4} & $\begin{array}{l}\text { Die Grundformen des Außenhandels } \\
\text { Direkter und indirekter Export//mport und Transithandel }\end{array}$ & 52 \\
\hline & $\begin{array}{l}\text { Going Through the Right Channels } \\
\text { Distribution channels and export/import intermediaries on domestic and } \\
\text { foreign markets }\end{array}$ & 58 \\
\hline
\end{tabular}

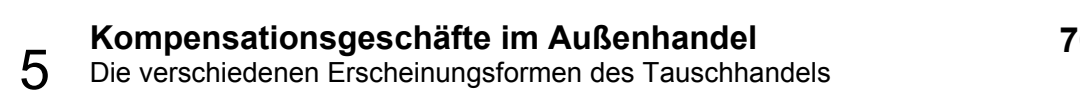
Alternative Routes
Alternatives to exporting: foreign direct investment, licensing, franchising,
joint ventures etc.

76

\begin{tabular}{l}
\hline $6 \begin{array}{l}\text { Die rechtlichen Rahmenbedingungen im Außenhandel } \\
\text { Rechtliche Aspekte, die von Importeur und Exporteur bei Außenhandels- } \\
\text { transaktionen zu beachten sind } \\
\text { Signed and Sealed } \\
\text { The sales contract }\end{array}$ \\
$7 \begin{array}{l}\text { Allgemeine Geschäftsbedingungen } \\
\text { Die verschiedenen Aspekte des Kleingedruckten im Kaufvertrag }\end{array}$ \\
$\begin{array}{l}\text { Delivering the Goods } \\
\text { Terms of delivery, INCOTERMS }\end{array}$ \\
$\begin{array}{l}\text { Konfliktmanagement mit Hilfe des Schiedsgerichts- } \\
\text { verfahrens } \\
\text { Das Wesen der Schiedsgerichtsbarkeit und ihre Vorteile für Unternehmen } \\
\text { Keeping the Peace } \\
\text { Dispute resolution }\end{array}$
\end{tabular}

86

90

98

102

112 
Der Gütertransport

9 Die Vor- und Nachteile der verschiedenen Transportarten

All Shipshape and Bristol Fashion

Logistics and transport management

Versanddokumente im Außenhandel

Getting the Paperwork Right

The main shipping documents

Risikomanagement im Außenhandel

11 Außenhandelsrisiken und die Möglichkeiten ihrer Minimierung

Better Safe than Sorry

Cargo insurance

\section{Zahlungsbedingungen im Außenhandel}

12 Zahlungsbedingungen und -instrumente

Settling Up

Bill of exchange and letter of credit

E-Commerce - zwischen Euphorie und Ernüchterung

Moderne elektronische Handelsplattformen

Pile it High, Sell it Cheap

178

The retail trade - yesterday, today and tomorrow

\section{Das Bankensystem in Deutschland}

14 Deutsche Banken im Überblick

Banking on Banks

Survey of the American and British banking systems

Die klassischen Bankdienstleistungen

15 Das klassische Leistungsangebot der Banken im Kleinkundengeschäft

All Change!

Recent developments in banking

Unternehmensformen - Personengesellschaften im Fokus

16 Von OHGs, KGs, GbRs und anderen Unternehmensformen

The Body Corporate

Types of corporation

Unternehmenszusammenschlüsse: Kooperation oder

17 Konzentration

Firmenzusammenschlüsse und andere Verbindungen

What's It Worth?

Company evaluation 
18 Einführung in die Rechnungslegung nach HGB, US-GAAP und IAS/IFRS

19 Begriffsbestimmung und Varianten von M\&As sowie eine Beschreibung des Fusionsprozesses

Companies in Distress

Insolvency and bankruptcy procedures

\section{Die Unternehmensorganisation}

20 Innere Firmenstrukturen

Corporate Structures

Company departments and typical organisational structures for companies with overseas operations

\section{Corporate Governance}

21 Shareholder versus Stakeholder Value

Management Buzz Terms

Outsourcing, benchmarking, TQM, kaizen, coaching and mentoring,

knowledge management and enterprise risk management

22 Deutschland

Mitbestimmung und Aufsichtsratssystem in Deutschland

Board Games

The Anglo-American board system

Kurzfristige Kapitalbeschaffung am Geldmarkt

23 Rund um den Geldmarkt

Capital Solutions

The world of corporate finance

24 Kapitalbeschaffungsmöglichkeit für Unternehmen

Hauptmerkmale der Aktie als Anlageinstrument

Forging Bonds

Main features and types of bonds

Neuemission und Börsengang eines Unternehmens

25 Der Primärmarkt

Securities trading on secondary markets 
Konjunkturpolitik im Banne des Magischen Vierecks

26 Beschäftigung, Preisstabilität, Wirtschaftswachstum und außenwirtschaftliches Gleichgewicht

Community Spirit

414

European Union: stability and growth in the eurozone, overview of the development, institutions and decision-making procedures of the EU

\section{Die Geldpolitik}

27 Varianten der Geldpolitik und inr Instrumentarium

Holding the Purse-Strings

Fiscal policy and the budget

\section{Wirtschaftstheorie im Wandel der Zeit}

28 Bedeutende Ökonomen und wirtschaftliche Denkschulen

The State Versus the Market

A closer look at Keynesianism and monetarism 